\title{
Toward projectified environmental governance?
}

\section{Munck af Rosenschöld, Johan}

2017

Munck af Rosenschöld , J \& Wolf , S 2017 , ' Toward projectified environmental governance? ' , Environment and Planning A , vol. 49 , no. 2 , pp. 273-292 . https://doi.org/10.1177/0308518X16674؛

http://hdl.handle.net/10138/306479

https://doi.org/10.1177/0308518X16674210

acceptedVersion

Downloaded from Helda, University of Helsinki institutional repository.

This is an electronic reprint of the original article.

This reprint may differ from the original in pagination and typographic detail.

Please cite the original version. 
Post-print. Published in Environment and Planning A. Copyright: SAGE Journals

https://doi.org/10.1177/0308518X16674210

\title{
Toward projectified environmental governance?
}

\author{
Johan Munck af Rosenschöld ${ }^{1,2} \&$ Steven A. Wolf ${ }^{1}$ \\ ${ }^{1}$ Cornell University, USA \\ ${ }^{2}$ University of Helsinki, Finland
}

\begin{abstract}
Projects are often praised for their efficiency, responsiveness to local context, and capacity to spur innovation, especially in comparison to more permanent organizations. Projects - cross-cutting organizational forms chartered to advance well-defined objectives during a specified period of time - have been a staple organizational form in the private sector, but only recently have scholars started to evaluate their relevance to governance within developed economies. In this paper we explore projectification - i.e., expanded reliance on temporally-bounded organizations - as a conceptual frame to advance understanding of environmental governance and as an empirical vehicle to incorporate temporal scales into a literature that has largely been focused on questions of spatial scale and levels of social organization. Through a case study of the United States Department of Agriculture's recently created Regional Conservation Partnership Program, we critically assess the concept of projectification. Based on interviews with key policy analysts and administrators and a review of policy documents, we critically evaluate prospects for project forms to empower local actors, produce new knowledge, and disrupt the policy field.
\end{abstract}

Keywords: Governance, project, temporality, agri-environmental policy, conservation

\section{To cite this article please use the following reference:}

Munck af Rosenschöld, J. \& Wolf, S.A. 2017. Toward projectified environmental governance? Environment and Planning A, 49(2): 273-292 


\section{Introduction}

Projects are often praised by boosters for their efficiency, responsiveness to local context, and capacity to spur innovation, especially in comparison to more permanent organizations (Gallagher 2015; see also Sjöblom and Godenhjelm, 2009). Projects - i.e., cross-cutting organizational forms chartered to advance well-defined objectives during a specified period of time (Lundin and Söderholm, 1995) - have been a staple organizational form in the private sector, but only recently have scholars started to evaluate the relevance of projects in public policy and governance in developed economies (Andersson, 2009; Sjöblom, 2009; Wolf, 2012; Allan, 2012). The trend toward projects has been dubbed 'projectification', the "increasing reliance on temporary organisations, typically projects, in order to enhance action and strategic effort" (Godenhjelm et al, 2015, page 328).

The aim of this paper is to establish the utility of engaging projects theoretically and empirically to advance critical understanding of environmental governance. We argue that projectification is consistent with current understanding of governance and the ostensible 'turn from government to governance' (cf. Rhodes, 1997). We explore the potential of the projectification thesis - i.e., expanded reliance on temporary organizations in society has social, economic, and ecological significance - to open up new lines of research related to temporal dimensions of governance. To date, the field of environmental governance has grappled meaningfully with questions of multi-level governance, territorial governance, and cross-sectoral (i.e. state, market, civil society) governance, all of which imply a departure from a simple, state-centered perspective and a concern with dynamics at multiple sites or spatial scales. While sustainability invites reflection on the past and the future, little theoretical or empirical work in environmental governance has been directed toward the axis of time (Sjöblom et al, 2012). We argue that projects provide us with a temporal frame through which we can advance analysis of participation and innovation, which we believe to be core foci structuring critical engagement with governance. Our aim is not to celebrate or denigrate project forms. Rather, we engage projects in order to expand our capacity to make sense of governance. 
In advancing this program of research and evaluating the usefulness of the projectification thesis, we empirically assess agri-environmental policy (AEP) in the United States (U.S.). Agriculture is the leading land use in the country (Nickerson et al, 2011), one of the largest sources of water pollution (U.S. EPA, 2002) and the source of roughly $8 \%$ of greenhouse gas emissions (U.S. EPA, 2016). We focus on the most recently created federal agrienvironmental program, the Regional Conservation Partnership Program (RCPP), which was legislated by Congress in 2014 and implemented in 2015 by the Natural Resources Conservation Service (NRCS) of the U.S. Department of Agriculture (USDA). The RCPP is built on the notion of partnerships between agricultural producers and local/regional nonprofit organizations, government agencies, corporations, and universities. Under short term funding agreements, these actors cooperate to advance projects focused around development, implementation, and assessment of natural resource conservation interventions. The RCPP represents a useful opportunity to engage ideas of projectification in no small part because AEP is characterized by a high degree of centralized bureaucratic control (Potter and Wolf, 2014; Batie, 2009). Local farmers in some states and counties have a voice in expressing how programs are administered and how federal money is to be spent, but traditions of local participation are highly variable across the country. Despite pressures for AEP reform and policy innovation over past decades, USDA has retained a model of policy and practice in which they pay for and deliver conservation programs to farmers through an extensive network of more than 2500 county-level offices all of which are staffed by USDA employees. Within this specific policy domain, locally-based project forms have been more or less nonexistent up to this point in time. This empirical case allows us to highlight the stakes attached to the projectification thesis and to demonstrate how the concepts can be operationalized to advance critical analysis of environmental governance.

The article is structured as follows. In section 2 we juxtapose brief reviews of environmental governance (EG) and project governance (PG) in order to highlight correspondence and productive tensions between the two literatures. Our review allows us to derive questions about participation and innovation that structure empirical engagement. To assess the 
usefulness of the projectification thesis, in section 3 we present a case study of the RCPP based on interviews and document review. In section 4 and 5 we discuss results of the case study and conclude through laying out a set of questions that can support critical engagement with the projectification thesis and expanded engagement with temporality.

\section{Situating projectification within environmental governance}

\subsection{Central themes in environmental governance}

The environmental governance literature has been assessed through reference to i) globalization, ii) decentralization, iii) market-based policy designs, and iv) cross-scale interactions (Lemos and Agrawal, 2006). While we could problematize reliance on this specific set of headings, these terms usefully summarize a set of important and inter-related concerns about the context, substance, and challenges of governance (see e.g. Rhodes, 1997; Hajer and Wagenaar, 2003; Bulkeley, 2005; Heynen et al, 2007). This framing of governance allows us to demonstrate correspondence between questions that structure the environmental governance and project governance literatures (see section 2.3 below).

The environmental governance literature has shed important light on the uneven process of moving away from nation-states as the prime actors of social regulation (McMichael 2012). Increased transnational flows of capital, goods, people, ideas, and environmental risk problematize the hegemony of sovereign nation states. The opening created by the diminished capacity of nation states has contributed to expanded opportunities for exercise of authority by supra-national institutions, multi-national corporations, civil society organizations and variously scaled communities (Okereke et al, 2009; Schroeder, 2010). This destabilization has served to blur traditional distinctions between identities and functions of 'public', 'private' and 'civil society' organizations. Occurring alongside the push up in scale, we observe decentralization, a tendency to empower sub-national levels of government as well as non-state actors. Skepticism directed toward the capabilities of national governments 
and bureaucracies to reduce and manage environmental degradation, and the implications of vesting government elites with additional coercive authority, is a central element of the discourse of decentralization (Dryzek, 1997). Part of the ostensible incapacity of nationallevel bureaucracies to manage complex environmental problems stems from a perceived information deficit (Mazmanian and Kraft, 2008). Understanding the drivers and crafting and implementing solutions to environmental problems requires in-depth knowledge of local conditions and a level of embeddedness in local contexts (Pritchard et al, 2016). A response to this information deficit has been to focus on local communities (Dietz et al, 2003), municipalities (Lindseth, 2005), and collaborative, participatory approaches to governance (Hajer and Wagenaar, 2003; Newig and Fritsch, 2009). Engaging and empowering actors working at local levels is understood as an effective and efficient way to access and to synthesize relevant information (Ostrom, 1999). Additionally, involving local people and a more diverse set of people is seen as enhancing the legitimacy of decision-making processes and outputs (Bulkeley and Mol, 2003).

Critical studies of decentralization, especially within the field of political ecology, have reminded us that rescaling governance to lower levels of social organization is not a onesize-fits all solution to the problem of social inclusion (e.g. Ribot, 2005). The local level is not devoid of power inequalities, and the risk remains that certain classes of actors will be over- and underrepresented in processes of resource allocation and rulemaking (e.g. Agrawal and Gibson, 1999; Cohen and Bakker, 2014).

Governance and empowerment of non-state actors is signified by expanded emphasis on 'new environmental policy instruments' (NEPIs). The novelty of these instruments relative to traditional bureaucratic and law-based regulation lies in their reliance on market rationality. In recent years, market-based policy instruments have come to be understood as 'hybrid,' signifying the interplay between market, network, and hierarchical modes of coordination (Jordan et al, 2005; Lemos and Agrawal, 2006; Potter and Wolf, 2014). In line with the logic of decentralization, the core idea of the introduction of NEPIs is that government planners are poorly positioned to gather and integrate relevant information and 
knowledge. Extending flexibility to regulated entities and allowing them to make decisions based on their knowledge of costs and benefits serves to enhance the efficiency of interventions. The prominence of NEPIs is often understood to reflect the introduction of neoliberal thought into environmental policy (see e.g. Lockie and Higgins, 2007). In debates about social responses to environmental problems, promises of speed, precision, cost effectiveness, and freedom from political capture have proven powerful.

In addition to attention to movement of authority upwards and downwards, interest in scale has animated the field of environmental governance. Because of biophysical and sociocultural heterogeneity and recognition of interdependencies between global, national, regional and local dynamics, design and analysis of environmental governance demands attention to cross-scale interactions (Paavola et al, 2009; Cohen, 2012). For example, Bulkeley (2005) argues that governance spans territorial boundaries, and localities should not only be seen simply as vertically situated 'under' the nation-state, but also as a node in a global network of localities. Similarly, the periphery has been understood traditionally as a passive receiver of influence from the center, but taking the notion of cross-scale governance seriously enables us to realize the capacity of local and peripheral actions and actors to influence the core. Based on recognition of the need to attend to multiple scales and levels of social organization, multi-level governance (e.g. Betsill and Bulkeley, 2006) has emerged as a core concept.

\subsection{Projects as organizing work and practice}

The concept of project has been incorporated into a broad range of contexts in recent decades. Project management has become a familiar way to structure work in and across organizations (Lundin and Söderholm, 1995). Typically, a project can mean everything from an intense short-term effort to an important assignment. In the project research literature there have been numerous attempts to define what a project is, and scholars working from different disciplines and traditions emphasize different types of questions. Research on projects can be divided into two general streams: a rationalistic tradition that builds on engineering 
science and operations research, and a critical tradition that views projects through a social scientific lens (Söderlund, 2004). While there is pronounced diversity, most definitions of projects insist that they are i) limited by a specific time frame, ii) task-oriented, iii) advanced by a designated team of actors, and iv) initiated to achieve change or establish novel processes (Lundin and Söderholm, 1995; see also Packendorff, 1995).

First, projects embody the notion of temporality. Compared to more permanent organizations such as firms and public sector agencies, projects have an end date after which time they are disbanded. Second, the focus of a project tends to be on performing specific tasks to address a specific objective rather than responding to organizational goals or an overarching mission. To carry out these tasks, projects are assigned limited resources - e.g. people, finances, and authority - that enable and constrain project activities (Lundin and Söderholm, 1995). In this sense projects are closely aligned with the notion of 'adhocracy' i.e. mode of governance in which cross-cutting, built-for-purpose organizations are created in response to specific problems of limited scope with the expectation that they will be collapsed, and the resources reallocated, when the relevant objectives are realized (Mintzberg, 1979). Third, the success of projects rests on relationships among the core team, the assigned group of actors with dedicated work tasks and responsibilities, and interactions with stakeholders, actors that have an interest in project processes or outcomes (e.g. Tryggestad et al, 2013). The inclusion of external actors can serve (at least) two purposes: it allows for knowledge exchange and integration between the project team and the environment in which they are working (Bakker et al, 2011; Kotnour, 2000), and it serves to enhance legitimacy and acceptability of outcomes (Rowley, 1997, page 889).

Finally, projects are ostensibly designed to generate new and unique practices in a particular field. Projects are generally seen as focused on generating a "non-routine process and/or...non-routine product" (Packendorff, 1995, page 327) that has the potential to produce transformative change (Lundin and Söderholm, 1995). Projects are identified as valuable sites for experimenting with novel ideas in pursuit of innovation (Sydow et al, 2004; Lindkvist, 2008). Projects enable team members, who often are affiliated with quasi- 
permanent organizations, to detach themselves from their daily work routines and to engage a specific objective for a limited period of time. This freedom, change in context, and interactions among individuals with different knowledge and networks are seen as ingredients for creative problem solving and learning (Nilsen, 2013). Projects can be focused on exploitation of existing knowledge, such as applying existing designs and techniques in new contexts, and exploration that yields new knowledge (cf. March, 1991; Brady and Davies, 2004). To the extent that projects are vehicles for exploitation, they will respond to prescribed problems and implementation plans. To the extent that projects function in an exploratory mode, they will exhibit more autonomy, more critical engagement, and greater scope for innovation that will disrupt existing governance arrangements. This distinction is useful for making sense of the structure, function, and potential of projects in various contexts.

Applied to the type of public sector governance we address in this paper, projects are situated within programs. A project is a single, temporary organization that is initiated to achieve a specified goal. A program is a collection of projects, each of which links to the broader goals of the program. Programs may spawn projects with distinct goals and little apparent overlap, or projects may be clustered around a set of narrow themes and targets with the hope of realizing synergies (Wirick, 2009). Projects and programs are nested levels of goal-oriented social action.

It is important to stress that discussing the use of projects in environmental governance is not a hypothetical exercise, as European Union (EU) regional policy represents a highly visible example of the institutionalization of project forms in public administration (Andersson, 2009; Godenhjelm et al, 2015). For the period of 2014-2020, the EU has allocated 351.8 billion euros towards three funds: European Regional Development Fund, Cohesion Fund, and European Social Fund. Under this model, each EU member state creates sub-national programs based on regional priorities. Project proposals are articulated by groups and organizations on the regional and local level, who collaborate to advance a wide range of relevant activities including improving water quality and protecting biodiversity. Project 
teams can consist of representatives from private companies, not-for-profit organizations, governmental agencies, and local governments. The duration of projects varies from 1-7 years, but cannot extend beyond the end of the programming period. The managing authorities exercise oversight over projects by enforcing reporting requirements on activities and spending.

\subsection{Projectification and implications for environmental governance research}

We seek to highlight correspondence between the environmental governance (EG) and project governance (PG) literatures in order to identify opportunities to strengthen existing research traditions and to advance new lines of inquiry applied to the challenges of participation and innovation in environmental policy and management. Identifying tractions between the literatures presented earlier serve as a point of departure for this endeavor.

Both EG and PG share an implicit reference to departure from a rigid, monolithic institutional environment, and they place significant emphasis on the expanded pool of actors engaged in contemporary processes of development and decision making. Whereas EG is concerned with the expanded opportunities for non-state actors to influence policy and engage in policy implementation, PG places emphasis on the participation of actors with different knowledges, competencies, and structural positions. Both traditions view breaking down administrative and knowledge silos as important, and they share a focus on construction of linkages among public, private, and civil society actors. The opening up and the relaxation of boundaries/roles that defined governance in a nation state-centered world have given rise to concerns about participation and democratic practice (Gutmann and Thompson, 2004). As with critical accounts of environmental governance that emphasize risks of unequal participation of different social groups (e.g. Agrawal and Gibson, 1999), studies of project governance have similarly identified unevenness in levels and depths of participation (Munck af Rosenschöld and Löyhkö, 2015). Kovách and Kučerová (2009) identify a new professional elite, "the project class", which is composed of those people with the social capital and the skill set to profit from governance through projects. 
Conceptualizing projects as distinct from more permanent organizations corresponds closely to the notion of decentralization and polycentrism (Ostrom, 2010) in the EG literature. Emphasis on the knowledge and agency of local actors lies at the heart of the program and the analysis of neo-endogenous development (Shucksmith, 2010). By virtue of their peripheral status (administratively and sometimes geographically), projects can be experimental spaces and allow for adaption to local contexts. Projects serve to cut across organizational boundaries, and this multi-sectoral and multi-level impulse resonates with the emphasis on non-state actors in EG. In both traditions, there is an emphasis on broader and deeper social inclusion of local actors (Sjöblom and Godenhjelm, 2009). Integrating different actors and sharing knowledge is linked to potential to enhance efficiency, effectiveness, and equity. Interestingly, in the EG tradition, decentralization and participation are often understood as a means of enhancing accountability. In a world of PG, it is possible that there are expanded opportunities for people to exercise their voices, but there is also the potential for an accountability gap in situations characterized by freedom from bureaucratic routines and controls.

Projectification has close parallels with the proliferation of market-based policy instruments within the EG discourse. Because of their short life span, there is a sense that projects are well-equipped to bring resources to bear when and where needed, or in a 'just-in-time' manner, compared to more permanent organizations (Rämö, 2004). In line with the logic of markets, project forms are seen as efficient and effective mechanisms for accessing and integrating relevant information and resources. This focus on allocative efficiency and a rejection of the superiority of bureaucracies in information processing maps closely onto neoliberal rationality (Castree 2008; Busch, 2014). Within the EG tradition, the 'neoliberalization of nature' tradition has developed an important critique of market-based environmental policy instruments (Heynen et al, 2007). A critical literature focused around projectification is largely lacking (for a start in this direction, see Sjöblom et al, 2012), but these lines of interrogation are fully relevant for probing the roots and the implications of proliferation of project forms. 
The EG literature places emphasis on cross-scale interactions and the interfaces that enhance coordination across levels of social organization. Analogous concerns arise in specifying relations between projects and more permanent organizations. Projects are short-term organizations that are generally dependent on resources provided by permanent organizations (i.e., inputs such as personnel, funding, and operational authority). Similarly, in order to catalyze significant outcomes, project outputs must be integrated into the operations of permanent organizations. This challenge of scaling up project practices and experiences is commonly recognized in the transition management literature (e.g. Geels, 2010). One of the difficulties here lies in translating knowledge embedded in projects in a manner that it becomes relevant and accessible to a wider audience (Sydow et al, 2004; Bakker et al, 2011). The challenge can then be understood in terms of making sense of knowledge production and the distribution of effective authority at and across multiple scales (Godenhjelm et al, 2015).

The EG literature has, by and large, not engaged explicitly with time, and this stands as an important point of contrast with the PG literature. Temporality is a cornerstone in the study of projects (Lundin and Söderholm, 1995), as the ephemeral nature of these organizations imparts important properties and offers potential benefits to their sponsors. There may be costs as well. The ability to make learning in projects cumulative and avoid reinventing the proverbial wheel presents important challenges, and in this context permanent organizations have potential advantages. Sjöblom addresses this ambiguity explicitly, as he identifies "the tension between short-term devices and long-term objectives" (Sjöblom, 2009, page 167, italics in original). Can creation of large numbers of localized projects yield long-term sustainable development? This question requires attention to flexibility and coordination in policy design, implementation, and assessment (Sjöblom and Godenhjelm, 2009).

Study of projects highlights ways in which the planning horizons of organizations enable and constrain coordination and collaboration. Dille and Söderlund (2011) note that projects are often situated in multiple institutional environments and composed of multiple actors with conflicting time schedules and planning horizons. Failing to meet the diverse expectations of 
the broader context can consequently lead to temporal misfits between projects and the institutional environments. In line with the multidimensional concept of proximity (Torre and Rallet, 2005), organizations that privilege similar time frames are likely to encounter lower friction in efforts to collaborate. For example, a philanthropic foundation may find it challenging to partner with an institutional investor. Given that environmental governance is premised in large part on building functional linkage among diverse organizations and across levels of social organization, ideas about the relationship between time and organizational forms have value for analysis and practice of environmental governance.

This compact review has illustrated some of the key connections between the environmental governance and project governance literatures, and it provides us with a tentative theoretical basis supporting the projectification thesis. This exercise allows us to identify key considerations and questions that structure operationalization of the concept of projectified governance. First, attention to distributed (localized), short-term projects highlights how governance is organized. In projectified environmental governance we expect to see expanded reliance on ephemeral organizations operating at some distance from public agency administrators and relevant public sector controls. Second, in projectified environmental governance there is potential for empowerment of a broader pool of actors and different knowledges. Third, emphasis on local context and adaptability focuses attention on the specification of problems and interventions that structure engagement with the environment. In projectified environmental governance, flexibility and expanded scope for engaging environmental problems presents opportunities for innovation. Our argument is not that projectification entails a 'shift', as such, in environmental governance, but that it forms a dimension of governance that has thus far mostly been unacknowledged. 


\section{Project forms in U.S. agri-environmental policy: A case study of the Regional Conservation Partnership Program}

\subsection{Data and methods}

We conducted a case study of the USDA's Regional Conservation Partnership Program (RCPP) to serve as a 'plausibility probe'; an "attempt to establish that a theoretical construct is worth considering at all, that is, that an apparent empirical instance of it can be found" (Eckstein, 1992, p. 148). This qualitative case study is structured to develop and test theory and to lay the groundwork for further scientific elaboration (Peters, 1998; Rueschemeyer, 2003; Flyvbjerg, 2006). The case study was conducted between September 2014 and January 2015. First, we collected and analyzed key policy documents relating to the RCPP (Congressional legislation, USDA program announcements, RCPP webpage maintained by NRCS). Analysis of these data was informed by the questions we derived from engagement with theory (see section 2.3) and from the three dimensions of projectification specified below. At the same time, in analyzing the texts, we remained open to emergence of new themes and theoretical interpretations.

Second, we conducted twelve semi-structured interviews with USDA and NRCS administrators, NRCS program and technical staff, Congressional committee staff, agrienvironmental policy analysts in federal agencies and NGOs, and leaders of projects supported by RCPP funds. Interviews were conducted with the specific people most knowledgeable of the issues under investigation, based on a theory-driven approach to the case study (Walliman, 2006). The interviews were conducted in person in Washington D.C. in the offices of the interviewees or by telephone. The interview guide we used to structure interactions addressed the history of the RCPP, its organization and implementation, and the aspirations various actors attach to it. Throughout the interviews we invited respondents to express how RCPP is similar to and different from other NRCS programs of the past and present. As semi-structured interactions, all interviews progressed in a similar manner, but 
allowed for elaboration and focus as determined by the interests and professional roles of the respondents (cf. Cassell, 2009).

Based on our theoretical treatment of projectification we rely on three questions to structure empirical analysis of the RCPP. We assess i) the extent to which the RCPP formalizes reliance on project forms within AEP (how is conservation work organized?), ii) the extent to which the RCPP serves to broaden the pool of actors empowered within AEP (who is engaged in conservation and whose knowledge is recognized?), and iii) the extent to which the RCPP serves to expand the scope of engagement and flexibility in specification of conservation priorities within AEP (which conservation problems are addressed?). This assessment positions us to assess the extent to which the RCPP represents a new trajectory within AEP in terms of organization and scope for participation and innovation. Our purpose in this paper is not to 'measure' projectification by counting projects relative to some baseline. Our focus is on mobilizing the projectification thesis to engage critically with multiscalar, diverse, uneven, and perhaps contradictory dynamics that characterize social inclusion and problem definitions in contemporary environmental governance.

\subsection{AEP in the United States as traditionally practiced}

While the conservation mission of the USDA has grown and there are measures of diversity at local levels, the 'format' of agri-environmental policy in the US has been defined by remarkable stability over the past 30 years. This stability of AEP is a product of a particular history. In 1985 a diverse political coalition formed and funding was allocated to support USDA's development and delivery of conservation programs to farmers who chose to participate. Over time, the mix of programs and the administrative rules of the programs as realized in individual states have changed, but the basic mechanisms and the underlying political coalition have remained intact (Potter and Wolf, 2014; Wolf, 2014). Conservation within AEP rests on funding contracts between USDA and individual agricultural producers. Payments are made to farmers for taking land out of production or for implementing standardized NRCS-approved technical practices that advance a formalized set of priorities. 
NRCS maintains offices at the state and county levels. In some local settings, local farmers as represented in Soil and Water Conservation Districts and county-level technical committees interface with USDA personnel in the implementation of AEP.

In exploring tensions between hierarchical and decentralized models of administration it is important to recognize these constructs as ideal types. In efforts to characterize practice in a large organization operating many different programs in many different local settings, we observe tendencies toward both centralization and decentralization. As Mathews (2011) has argued, we should not endow bureaucracies with unwarranted capabilities and coherence. The knowledge and the capabilities of central authorities always derive in part from contributions of and relations with local actors. Gilbert's (2015) analysis of democratic practice within the USDA of the 1930's New Deal and the frustrations dealt to champions of local autonomy highlight the long and indeterminate history of agricultural and rural development policy within USDA. While the administrative practices of NRCS cannot be easily described in categorical terms, over time there is a tendency toward increasing regimentation and hierarchical controls.

While NRCS relies heavily on internal resources and capabilities, the agency has selectively introduced reforms in response to pressures from inside and outside the agency over the past thirty-year period. For example, as is the case in many political domains, there has been a measure of decentralization. State-level NRCS offices are more engaged in conservation priority setting than in the past (USDA, 2015) and there has been limited engagement with third party service providers (USDA, 2002). Secondly, critics have identified conservation programs as poorly targeted, and there has been sustained pressure to enhance costeffectiveness (Batie, 2009; Doering et al, 2013). In response, NRCS has developed a variety of scoring and ranking tools to support decisions about which farmland to enroll in conservation programs. Lastly, in response to a critique of the evidence base on which AEP is founded, NRCS initiated a ten-year long review of the science guiding their actions (Duriancek et al, 2013). Each of these examples of pressure-and-response highlights the ability of NRCS to adapt in ways that reinforce the legitimacy of their programs without 
changing the format of AEP (Potter and Wolf, 2014). AEP and NRCS have proven resilient, which highlights capacity to deflect and to adapt in response to criticism and new ideas.

\subsection{The Regional Conservation Partnership Program}

The Regional Conservation Partnership Program (RCPP) was authorized by the Agriculture Act of 2014. Funding was dispersed through the program for the first time in May 2015. The overarching vision of the program is stated in the following terms,

RCPP offers new opportunities for NRCS to work with partners to encourage locallydriven innovation and create high-performing solutions, harness innovation, accelerate the conservation mission, launch bold ideas, and demonstrate the value and efficacy of voluntary, private lands conservation...RCPP provides for increased coordination across conservation program activities while doubling resources through partner contributions to address resource concerns at the regional level. Successful partnerships will bring an array of financial and technical capabilities to projects, including cash contributions, technical professionals, and assessment experts.

(USDA, 2014, page 7)

RCPP funds delivery of technical assistance to private landowners by public, private, and civil society organizations recognized as eligible under the program (e.g. local government, dedicated regional authorities, universities, not for profit organizations, private firms). Additionally, RCPP funds can be used to develop technical assistance capabilities (e.g. natural resource assessment, conservation practice survey and design, conservation planning, and resource monitoring). The duration of the projects varies between 1-5 years. The RCPP mainly grew out of experience with the Cooperative Conservation Partnership Initiative (CCPI) of 2009-2012, and an effort to consolidate NRCS programming. One hundred million dollars per year have been budgeted directly to the RCPP, plus NRCS has authority to spend 
up to $7 \%$ of funds dedicated to other NRCS conservation programs on RCPP activities. The expectation is that roughly $\$ 1.5$ billion will be spent through RCPP in the next 5 years.

NRCS publishes an open call once per year and evaluates the resulting proposals based on four variably weighted criteria (see Table 1). These criteria highlight important aspects of the RCPP and the structural context of this new program. The partnership model is premised on leveraging investments from other organizations. Contributions of money, equipment, or staff time are required from project partners during the period of NRCS funding. There is an expectation that some portion of projects will be self-sustaining after NRCS funding ends, and this reflects an aim to expand and extend impact by leveraging RCPP funding. Secondly, there is an emphasis on documenting outcomes. The effectiveness of AEP has been criticized by the federal government and by a wide range of advocacy organizations, and this has created an accountability gap (Wolf, 2014). NRCS wants to engage local actors to produce evidence of benefits. This evidence can be used to support organizational learning (i.e., scaleup successful experiments and a move away from practices that yield low returns on investment), and these data can be used to legitimate AEP. Finally, we observe emphasis on expanding working relationships with actors other than farmers and ranchers. This strategic effort reflects a need for NRCS to diversify the publics they support through their programs and who support them in the political arena (Fortmann, 1990).

---- INSERT TABLE 1 ABOUT HERE ----

\subsubsection{Organization of RCPP - How is conservation pursued?}

In terms of organization - i.e., structure of decision-making and resource allocation - RCPP is unconventional in two respects. First, the RCPP is presented as a vehicle for bottom-up, territorial development implemented through projects. Funded projects will bring local actors together to advance conservation in ways that they see as practical and relevant for their particular region. The RCPP allows NRCS to curate a collection of projects that feature 
various objectives, geographic foci, and partners. Catalyzing and funding local projects to advance conservation signifies a notable departure for NRCS. Funding and creating capacity in a diverse array of regional and local organizations is very different from the traditional NRCS format of building relations and contracting with individual landowners.

Second, the RCPP places emphasis on non-federal funding. It is expected that half of the funding for RCPP will be leveraged through partner contributions, and as shown in Table 1 project applications are evaluated based on the level of funding and in-kind contributions partners bring to projects. Private funding is seen as a way to strengthen conservation, generate increased awareness of the environmental implications of agriculture, and ensure USDA's partners are invested in the work of RCPP projects. Some regarded the focus on non-federal contributions as problematic, as it might put too much focus on funding, rather than project goals and deliverables.

It is the idea of tackling these very complex natural resource issues, but flipping it so it's not top-down, not government-down, not organization or whatever or NGO or agribusinesses top-down, but from the ground up. Farmers...they know how to get stuff done, and they know what matters to them, and they know how to do it at the local level. So why not give them the tools they need to solve this at the local level? So it was built around that idea.

(Interviewee 2)

\subsubsection{Actors in RCPP - Who is engaged in conservation?}

Analysis of who is engaged in conservation and whose efforts are supported are essential questions for assessing the significance of RCPP. In the context of RCPP, the word partner refers to organizations such as producer associations, state or local government, farmer cooperatives, institutions of higher education, and other organizations with a history of 
working with agricultural producers. A partnership must include private landowners and organizations prepared to work with landowners to advance conservation. This requirement distinguishes RCPP, as AEP has been predicated on dyadic relationship between NRCS and individual landowners. Providing funds to entities other than farmers represents an important shift.

Water utilities are one of the non-traditional partners that were identified as particularly interesting from the point of new actors in conservation. These organizations are seen as well positioned to support upstream farmers' efforts to manage land and runoff in order to mitigate the need for construction and maintenance of water treatment plants. In the UK (WynneJones, 2013) and in Latin America (Goldman et al, 2010), there is substantial optimism attached to integrating water management into agri-environmental planning and policy.

It was also argued that the RCPP could be important for agricultural producers operating outside of conventional commodity systems. One interviewee emphasized the importance of the introduction of a financial mechanism for delivering technical assistance to small groups of specialized producers. Farms that are part of major commodity sectors featuring widely practiced technologies generally have access to technical assistance. In this sense, the opportunity to access federal resources through collective action in peripheral regions or among actors invested in unconventional products and farming systems represents a way forward. Potential for the RCPP to support alternative agriculture and peripheral territories was, however, seen to be constrained by the funding mechanism and the contours of the traditional policy network. In order to develop a successful proposal under RCPP, one needs to have a good understanding of how the NRCS works, how it enters into conservation contracts, and the kind of language that is used. 


\subsubsection{Problem scope of RCPP - What is conserved?}

Conservation activities eligible for RCPP funding are specified as "[w]ater quality restoration or enhancement...[w]ater quantity conservation, restoration, or enhancement...[d]rought mitigation...[f]lood prevention...[w]ater retention...[a]ir quality improvement...[h]abitat conservation, restoration, and enhancement...[e]rosion control and sediment reduction...[f]orest restoration...[o]ther related activities that the Secretary determines will help achieve conservation benefits" (US House of Representatives 2014, page 97). Interviewees suggested that this list of topics reflects interest in being inclusive. Importantly, RCPP does not extend the USDA's range of conservation priorities, as this list conforms to the problems traditionally recognized by USDA. On this basis, there appears to be important constraints on the capacity of RCPP to respond to locally driven conservation concerns. The RCPP is focused on the development of new delivery mechanisms through which NRCS's knowledge is disseminated in the form of implementation of NRCS-approved conservation practices.

What they actually will do on the ground won't necessarily be all that new, but where they deliver it, or who they partner with, or how they communicate to the public, or how they measure the success that may well be very innovative... The actual activities will be fairly common...Potentially some new innovative conservation practices might come with partner funds, instead of using any federal NRCS funds to do it, given the complications of all the strings attached in the process.

(Interviewee 5)

Yet, interviewees pointed to flexibility in program administration. While conservation practices funded by RCPP must adhere to NRCS recognized standards, there are opportunities to petition for an adjustment or relaxation of standards if they do not fit the objectives of a project. In this sense, RCPP can be understood as focused on process innovation. 
It's very broad... And we want to maintain it that way as we implement RCPP...I can tell you that here's our programs that you can use, we're going to be flexible in how you want to implement those as long as we can do that flexibility and we're not breaking the statute...If we can adjust that regulation we will. So that's a flexibility that RCPP is giving us and the applicants and the implementers. But the bottom line is we want the applicants and the partners to tell us how they want to get conservation done and here's our tools you can use to do that with.

(Interviewee 1)

The RCPP was identified as different from the USDA's Conservation Innovations Grants (CIG) program, an effort specifically designed to produce new conservation techniques. Some interviewees were explicitly critical of the NRCS's support of conventional agriculture and the way that the bureaucratic structure and organizational culture constrain innovation in practices. The heavy emphasis in RCPP on generating evidence of benefits derived from approved conservation practices points to an eagerness to legitimate the suite of conservation practices that have long defined AEP.

\section{Discussion}

We assessed three aspects of the RCPP to evaluate the value of the projectification thesis in the context of U.S. AEP; reliance on temporal organizations, inclusion of new actors, and shifts in objectives. By going beyond a simple accounting of the status of short-term organizational forms, and asking questions about who gets resources and what activities are pursued, we are able to advance a critical and more comprehensive assessment. Because this program was initiated recently, it is too early to make definitive statements about outputs and outcomes. Through our case study we illustrate how projectification can inform research and extend understanding of contemporary environmental governance. 
Our analysis highlights that RCPP signifies a new trajectory in how NRCS distributes conservation funding and positions itself in conservation planning and implementation. Providing funds on a short-term basis to a diverse set of local and regional partnerships that seek to develop relationships and capabilities to support conservation on private lands differentiates RCPP from other NRCS programs and from the traditional model of AEP. Under an increasingly centralized administrative model, NRCS has provided funding and technical assistance to individual landowners to implement one or more codified conservation practices. The design of the RCPP suggests the creation of a large set of diverse and distributed organizations that support conservation. The projects can be seen as interfaces that lie between USDA and conservation activities. The implications of these linkages are not clear at this time, and the nature of the interfaces between projects and NRCS are not known. It is unclear if short-term projects will produce long-term benefits or result in organizations that persist after the NRCS funding is withdrawn. There is potential for these projects to produce lasting capabilities that complement those of NRCS, there is a chance that organizations that grow out of RCPP could come to perform some NRCS functions, and there is a possibility that these organizations could play a role in redefining conservation policy and practice. While future research is needed to respond to these questions, we can report that RCPP formalizes a commitment to project governance in AEP.

With regard to participation, RCPP is a vehicle for broadening the set of actors engaged in AEP. The creation of a funding mechanism that catalyzes the creation and scaling up of local and regional partnerships involving public, private, and civil society organizations is very different from the traditional approach to expanding participation. In the past, participation has been conceptualized narrowly in terms of expanding the pool of private landowners interested in enrolling in traditional NRCS programs. The 'opening up' of the category of who is participating in NRCS programs is not, in itself, indicative of democratization and normative ideals of social inclusion. We need to know more about the actors engaged in projects (cf. Kovách and Kučerová, 2009). Are they small, local entities or large 
agribusinesses and commodity organizations that already enjoy standing in the policy field? Additionally, we need to know more about the roles of non-traditional actors. To assess participation, we need data on whose interests, knowledge, and priorities structure projects and their outputs. Despite these questions and caveats, RCPP is notable for introducing new opportunities for a diverse set of actors to participate in AEP.

As platforms for interaction that remove actors from organizational routines and procedures, projects can advance innovation by allowing for experimentation with novel ideas and practices. Applied to the RCPP, the project proposals must address a set of environmental management priorities articulated by NRCS, and the conservation practices advanced by projects must correspond to an NRCS approved technique. Although there is some scope for modifying existing conservation techniques and relaxing procedural controls, we observe emphasis on producing locally effective, efficient, and socially acceptable means of delivering existing technical prescriptions. In this sense, our analysis of the RCPP suggests that organizing work in projects may in itself have little effect on the specification of conservation priorities. Conceptualizing projects as implementation vehicles is different from an understanding of projects as platforms for experimentation, and this difference is an important element of a critical appreciation of projectification. Referring again to the work of March (1991), to the extent that projects serve to exploit existing knowledge, they will be focused on realization of efficiency in implementation of existing techniques to prescribed problems. To the extent that projects serve an exploratory function, they will exhibit more autonomy and more critical engagement with existing problem definitions. At this time the RCPP is not in the business of empowering local people to specify conservation challenges and to craft solutions, and in this sense the 'innovation surplus' of these projects is likely to be low.

As highlighted in Table 2, the results of our assessment RCPP as a harbinger of projectification is mixed. We document formal engagement with project forms in AEP, which is novel, and we identify opportunities for these projects to integrate new sets of actors into the work of NRCS and into conservation on private lands. Because the work of projects 
is designed to be tightly aligned with the work of NRCS, there seems to be limited scope for RCPP to serve as a vehicle to change the conservation mission of NRCS. Rather than try to weigh and integrate these different results to support a unified conclusion about the extent to which AEP governance is projectified, we want to stress the multidimensionality of the concept and the relevant processes. Our focus on questions of organization, participation, and innovation allow us to highlight ways in which research on temporary organizations opens up new opportunities for environmental governance research.

\section{Conclusion}

The aim of this paper was to evaluate the utility of focusing on projects, and projectification, to advance our understanding of governance. We assessed governance through projects by studying the Regional Conservation Partnership Program (RCPP), a new agri-environmental policy (AEP) program legislated by U.S. Congress in 2014. The case study allows us to explore the significance of expanded reliance on project forms for participation and innovation, two key foci of the environmental governance and project governance literatures. Our analysis suggests that the RCPP represents a new trajectory in AEP and movement toward projectification. Providing short-term funding to support emergence and consolidation of local platforms for conservation that integrate public, private, and civil society actors is a potentially important departure from the standard model of funding farmers' application of conservation practices. In parallel, our findings highlight that aspects of the traditional model of AEP are manifested in RCPP. Although the utilization of projects to implement AEP is novel, the RCPP still relies on conventional problem definitions. Further, delivering NRCS-approved conservation practices to farmers remains the core focus of investment at this time.

In calling attention to projectification and highlighting the introduction of project governance into the specific domain of AEP, we do not claim that we are on the cusp of flipping into a new equilibrium (cf. Baumgartner and Jones, 1993). Policy change is generally slow, and 
inertia is powerful (Munck af Rosenschöld et al, 2014). Applied to AEP, projectification does not imply a clear pathway toward decentralization, relaxation of bureaucratic controls, and new opportunities for knowledge production. Expanded reliance on short-term organizations is an additional dimension in an uneven, complex, and contradictory organizational landscape. In making an effort to understand new developments and trajectories in a policy field, history and context are essential. Agricultural policy and the specific programs focused around environmental conservation have been subject to many decades of debate regarding where authority should reside (Gilbert, 2015). At present, AEP is subject to pointed accountability demands (Duriancik et al, 2008), and the dominant response is to talk about and to advance more evidence- and outcome-based programming (Batie, 2009; Doering et al, 2013; Potter and Wolf, 2014). Building new relationships with local partners and engaging them in documenting benefits can be a complementary response. Making sense of actors' interests and motivations in an historical and political economic context is an important element of any analysis of policy change.

Rather than attempting to provide a definitive assessment of how much projectification is observed, the case of RCPP serves to highlight the stakes attached to projectification and to illustrate how the concept can be operationalized to advance empirical research. As we have demonstrated, the projectification thesis allows us to derive questions that can expand understanding of contemporary governance and institutional change. Attention to increased reliance on projects in implementing policy and responding to social problems highlights a potentially important development in how environmental action is coordinated and orchestrated. The governance literature has usefully focused our attention on the relations between state and non-state actors and between global and local actors. Projectification presents us with an opportunity to address the roles of projects and the relations between short-term organizations and durable public and private sector actors. As Sjöblom and Godenhjelm (2009) have argued, short-term organizational forms are related to quasipermanent state bureaucracies and to local actors in uneven and variable ways, and these organizational considerations present us with important questions about the structure and performance of social coordination mechanisms. As our case suggests, projectification does 
not necessarily follow a clear trajectory toward an ideal-typical project logic. There is indeterminacy along many axes, and there is clear potential to layer project governance onto existing modes of governance. Future research on projectification would benefit from carefully examining the dynamics of projectification and the different forms it can take. Extensive private sector engagement with projects and an extensive literature should inform research on projectification applied to public administration and governance. Presumably there are parallels and important differences in terms of structure, function, and outcomes.

The concept of projectification advances our engagement with temporal dimensions of environmental governance. Specifically, a focus on projects provides us with a temporal frame or lens through which we can study participation and innovation, two central concerns of governance. To what extent does 'time compression' (Modig, 2007, page 808) in projects encourage or discourage participation, and how do the short time frames of projects affect the nature and the quality of participation? Reliance on project forms in governance has the potential to open up opportunities for expanded participation of local actors, sectors, and knowledges, such as suggested in the case of RCPP. Projects can cut across organizational boundaries and missions, and thereby produce new openness, but they can also obscure governance processes and sustain existing power structures. Proliferation of 'pop-up' organizations and appeals to urgency can undermine bureaucratic routines and commitments to procedural controls focused around transparency, informed consent, and social inclusion. The relationship between short-term organizational forms and democratic ideals such as citizen empowerment, deliberation, and accountability is context-dependent. Understanding these relationships is an important issue on the research frontier.

The temporary character of projects also raises important questions for the study of innovation in environmental governance. Projects have potential to serve as sites of experimentation and as platforms to generate proof-of-concept needed for an idea to gain legitimacy (cf. Johansson et al, 2007). Applied to RCPP, the innovative potential is constrained by funding rules that emphasize a need to rely on existing NRCS-approved conservation practices. Further, it is not clear if short term funding will produce lasting 
commitments and allow for scaling up and institutionalization of promising ideas. We identify a need to maintain a critical stance in studying innovation through projects, and we must situate projects within a broader organizational context. Rather than characterizing project governance as a distinct alternative to bureaucracies, future research should focus on relations between project forms and more permanent organizations (cf. Engwall, 2003).

\section{References}

Agrawal A, Gibson C C, 1999, "Enchantment and disenchantment: The role of community in natural resource conservation" World Development 27(4) 629-649

Allan C, 2012 "Rethinking the " Project ": Bridging the Polarized Discourses in IWRM" Journal of Environmental Policy \& Planning 14(3) 231-241

Andersson K, 2009, "Orchestrating regional development through projects: the "innovation paradox" in rural Finland" Journal of Environmental Policy \& Planning 11(3) 187201

Bakker R M, Cambré B, Korlaar L, Raab J, 2011, "Managing the project learning paradox: A set-theoretic approach toward project knowledge transfer" International Journal of Project Management 29(5) 494-503

Batie S S, 2009, "Green payments and the US Farm Bill: Information and policy challenges" Frontiers in Ecology and the Environment 7(7) 380-388

Baumgartner F R, Jones B D, 1993 Agendas and Instability in American Politics (The University of Chicago Press: Chicago) 
Betsill M M, Bulkeley H, 2006, "Cities and the multilevel governance of global climate change" Global Governance 12(2) 141-159

Brady T, Davies A, 2004, "Building Project Capabilities: From Exploratory to Exploitative Learning” Organization Studies 25(9) 1601-1621

Bulkeley H, 2005, "Reconfiguring environmental governance: Towards a politics of scales and networks" Political Geography 24(8) 875-902

Bulkeley H, Mol A P J, 2003, "Participation and Environmental Governance: Consensus, Ambivalence and Debate" Environmental Values 12(2) 143-154

Busch L, 2014, "How Neoliberal Myths Endanger Democracy and Open New Avenues for Democratic Action", in The Neoliberal Regime in the Agri-Food Sector: Crisis, Resilience and Restructuring Eds S A Wolf, A Bonanno (Earthscan/Routledge: Oxon) pp 32-50

Cassell C, 2009, "Interviews in Organizational Research". In D. A. Buchanan \& A. Bryman, eds. The SAGE Handbook of Organizational Research Methods. London: SAGE, pp. 500-515

Castree N, 2008 “Neoliberalising Nature: Processes, Effects, and Evaluations” Environment and Planning A 40(1) 153-173

Cohen A, 2012, "Rescaling environmental governance: Watersheds as boundary objects at the intersection of science, neoliberalism, and participation" Environment and Planning A 44(2) 2207-2224

Cohen A, Bakker K, 2014, “The eco-scalar fix: Rescaling environmental governance and the politics of ecological boundaries in Alberta, Canada" Environment and Planning D: Society and Space 32(1) 128-146 
Dietz T, Ostrom E, Stern, P C, 2003, “The struggle to govern the commons" Science 302(5652) 1907-12

Dille T, Söderlund J, 2011, "Managing inter-institutional projects: The significance of isochronism, timing norms and temporal misfits" International Journal of Project Management 29(4) 480-490

Doering O, Lawrence D, Helms J, 2013, “Agricultural conservation \& environmental programs: The challenge of data-driven conservation" Choices 28(2)

Dryzek J S, 1997 The Politics of the Earth: Environmental Discourses (Oxford University Press: New York)

Duriancik L F, Bucks D, Dobrowolski J P, Drewes T, Eckles S D, Jolley L, Kellogg R L, Lund D, Makuch J R, O'Neill M P, Rewa C A, Walbridge M R, Parry R, Weltz M A, 2008, "The first five years of the Conservation Effects Assessment Project" Journal of Soil and Water Conservation 63(6) 185A-197A

Eckstein, H, 1992 Regarding Politics: Essays on Political Theory, Stability, and Change (University of California Press: Berkeley)

Engwall M, 2003, "No project is an island: linking projects to history and context" Research Policy 32(5) 789-808

Flyvbjerg B, 2006, "Five Misunderstandings About Case-Study Research" Qualitative Inquiry 12(2) 219-245

Fortmann L, 1990, "The role of professional norms and beliefs in the agency-client relations of natural resource bureaucracies" Natural Resources Journal 30(2) 361-380

Gallagher S, 2015 Time, risk, and innovation: Creating space in your day to solve meaningful problems, 2015 PMI Global Congress Proceedings, Orlando, FL, USA 
Geels F W, 2010, “Ontologies, socio-technical transitions (to sustainability), and the multilevel perspective" Research Policy 39(4) 495-510

Gilbert J, 2015 Planning Democracy: Agrarian Intellectuals and the Intended New Deal (Yale University Press: New Haven)

Godenhjelm S, Lundin R A, Sjöblom S, 2015, "Projectification in the public sector - the case of the European Union" International Journal of Managing Projects in Business 8(2) 324-348

Goldman R L, Benitez S, Calvache A, Ramos A, 2010, "Water funds: Protecting watersheds for nature and people", The Nature Conservancy, Arlington, Virginia, http://www.naturalcapitalproject.org/pubs/TNC_Water_Funds_Report.pdf

Grabher G, 2004, "Learning in Projects, Remembering in Networks?: Communality, Sociality, and Connectivity in Project Ecologies" European Urban and Regional Studies 11(2) 103-123

Gutmann A, Thompson D, 2004 Why Deliberative Democracy? (Princeton University Press: Princeton)

Hajer M A, Wagenaar H, 2003 Deliberative Policy Analysis: Understanding Governance in the Network Society (Cambridge University Press: Cambridge)

Heynen N, McCarthy J, Prudham S, Robbins P, Eds, 2007 Neoliberal environments: False promises and unnatural consequences (Routledge: Oxon and New York)

Johansson S, Löfström M, Ohlsson Ö, 2007, “Separation or integration? A dilemma when organizing development projects" International Journal of Project Management 25(5) $457-464$ 
Jordan A, Wurzel R K W, Zito A, 2005, “The rise of "new”policy instruments in comparative perspective: has governance eclipsed government?" Political studies 53(3) 477-496

Kotnour T, 2000, "Organizational learning practices in the project management environment learning" International Journal of Quality \& Reliability Management 17(4/5) 393-406

Kovách I, Kučerová E, 2009, “The social context of project proliferation - the rise of a project class" Journal of Environmental Policy \& Planning 11(3) 203-221

Lemos M C, Agrawal A, 2006, "Environmental Governance” Annual Review of Environment and Resources 31(1) 297-325

Lindkvist L, 2008, "Project organization: Exploring its adaptation properties" International Journal of Project Management 26(1) 13-20

Lindseth G, 2005, "Local level adaptation to climate change: Discursive strategies in the Norwegian context" Journal of Environmental Policy \& Planning 7(1) 61-84

Lockie S, Higgins V, 2007, "Roll-out neoliberalism and hybrid practices of regulation in Australian agri-environmental governance” Journal of Rural Studies 23(1) 1-11

Lundin R A, Söderholm A, 1995, “A Theory of the Temporary Organization” Scandinavian Journal of Management 11(4) 437-455

March J G, 1991, "Exploration and exploitation in organizational learning" Organization Science 2(1) 71-87

Mathews, A S, 2011 Instituting Nature: Authority, Expertise and Power in Mexican Forests (MIT Press: Cambridge, MA) 
Mazmanian D A, Kraft M, 2008, “The Three Epochs of the Environmental Movement”, University of Southern California School of Policy and Development, Environment \& Sustainability, WP-March 2008-1. Available at SSRN:

http://dx.doi.org/10.2139/ssrn.1516819

McMichael P, 2012 Development and Social Change. A Global Perspective (SAGE: Thousand Oaks)

Mintzberg H, 1979 The Structuring of Organizations: A Synthesis of the Research (Prentice-Hall: Englewood Cliffs, NJ)

Modig N, 2007, “A continuum of organizations formed to carry out projects: Temporary and stationary organization forms" International Journal of Project Management 25(8) $807-814$

Munck af Rosenschöld J, Löyhkö J, 2015, “LEADER and local democracy: a comparison between Finland and the United Kingdom”, in Evaluating the European Approach to Rural Development: Grass-roots Experiences of the LEADER Programme Eds L Granberg, K Andersson, I Kovách (Ashgate: Farnham) pp 13-32

Munck af Rosenschöld J, Rozema J G, Frye-Levine L A, 2014, "Institutional inertia and climate change: A review of the new institutionalist literature" WIREs Climate Change $5639-648$

Newig J, Fritsch O, 2009, "Environmental governance: Participatory, multi-level - and effective?" Environmental Policy and Governance 19(3) 197-214

Nickerson C, Ebel R, Borchers A, Carriazo F, 2011, Major Uses of Land in the United States, 2007, EIB-89, U.S. Department of Agriculture, Economic Research Service. 
Nilsen E R, 2013, “Organizing for learning and knowledge creation - are we too afraid to kill it?: Projects as a learning space" International Journal of Managing Projects in Business 6(2) 293-309

Okereke C, Bulkeley H, Schroeder H, 2009, “Conceptualizing Climate Governance Beyond the International Regime Conceptualizing Climate Governance" Global Environmental Politics 9(1) 58-78

Ostrom E, 1999, "Coping With Tragedies of the Commons" Annual Review of Political Science 2(1) 493-535

Ostrom E, 2010, "Polycentric systems for coping with collective action and global environmental change" Global Environmental Change 20(4) 550-557

Paavola J, Gouldson A, Kluvánková-Oravská, T, 2009, “Interplay of Actors, Scales, Frameworks and Regimes in the Governance of Biodiversity" Environmental Policy and Governance 19(3) 148-158

Packendorff J, 1995, "Inquiring into the temporary organization: New directions for project management research" Scandinavian Journal of Management 11(4) 319-333

Peters B G, 1998 Comparative Politics: Theory and Methods (New York University Press: New York)

Potter C A, Wolf S A, 2014, "Payments for ecosystem services in relation to US and UK agri-environmental policy: disruptive neoliberal innovation or hybrid policy adaptation?" Agriculture and Human Values 31(3) 397-408

Pritchard S, Wolf S, Wolford W, 2016, "Knowledge and the politics of land" Environment and Planning A 48(4) 616-625

Rhodes R A W, 1997 Understanding governance: policy networks, governance, reflexivity and accountability (Open University Press: Maidenhead) 
Ribot J C, 2005, “Choosing Representation: Institutions and Powers for Decentralized Natural Resources Management", in The Politics of Decentralization: Forests, Power and People Eds C J Pierce Colfer, D Capistrano (Earthscan: London) pp 86-106

Rueschemeyer D, 2003, “Can one or a few cases yield theoretical gains?”, in Comparative Historical Analysis in the Social Sciences Eds J Mahoney, D Rueschemeyer (Cambridge University Press: New York) pp 305-336

Rämö H, 2004, "Moments of trust: temporal and spatial factors of trust in organizations" Journal of Managerial Psychology 19(8) 760-775

Rowley T J, 1997, "Moving beyond dyadic ties: A network theory of stakeholder influences" Academy of Management Review 22(4) 887-910

Schroeder H, 2010, "Agency in international climate negotiations: the case of indigenous peoples and avoided deforestation" International Environmental Agreements: Politics, Law and Economics 10(4) 317-332

Shucksmith M, 2010, “Disintegrated Rural Development? Neo-endogenous Rural Development, Planning and Place-Shaping in Diffused Power Contexts" Sociologia Ruralis 50(1) 1-14

Sjöblom S, 2009, “Administrative Short-Termism-A Non-Issue in Environmental and Regional Governance” Journal of Environmental Policy \& Planning 11(3) 165-168

Sjöblom S, Andersson K, Marsden T, Skerratt S, Eds, 2012 Sustainability and Short-term Policies: Improving Governance in Spatial Policy Interventions (Ashgate: Farnham)

Sjöblom S, Godenhjelm S, 2009, "Project Proliferation and Governance-Implications for Environmental Management" Journal of Environmental Policy \& Planning 11(3) $169-185$ 
Sydow J, Lindkvist L, DeFillippi R, 2004, "Project-Based Organizations, Embeddedness and Repositories of Knowledge: Editorial” Organization Studies 25(9) 1475-1489

Söderlund J, 2004, "Building theories of project management: past research, questions for the future" International Journal of Project Management 22(3) 183-191

Sydow J, Lindkvist L, DeFillippi R, 2004, “Project-Based Organizations, Embeddedness and Repositories of Knowledge: Editorial” Organization Studies 25(9) 1475-1489

Torre A, Rallet A, 2005, “Proximity and Localization” Regional Studies 39(1) 47-59

Tryggestad K, Justesen L, Mouritsen J, 2013, "Project temporalities: how frogs can become stakeholders" International Journal of Managing Projects in Business 6(1) 69-87

United States Environmental Protection Agency, 2002, 2000 National Water Quality Inventory Report, EPA-841-R-02-001

United States Environmental Protection Agency, 2016, Inventory of U.S. Greenhouse Gas Emissions and Sinks: 1990-2014, EPA 430-R-16-002

US House of Representatives, 2014, Agricultural Act of 2014 H.R. 2642, 113th Congress

USDA, 2002 Third Party Vendors in Conservation, U.S. Department of Agriculture, March 2002, Historical Insights Number 2, http://www.nrcs.usda.gov/Internet/FSE_DOCUMENTS/stelprdb1044425.pdf

USDA, 2014 RCPP Announcement for Program Funding, U.S. Department of Agriculture, May 27, 2014, CFDA number 10.930, Washington D.C., USA

USDA, 2015, "Setting Local Priorities Based on Local Input and Needs Assessment”, U.S. Department of Agriculture, http://www.nrcs.usda.gov/wps/portal/nrcs/detail/nc/home/?cid=nrcs142p2_046671 
Walliman N, 2006 Social Research Methods (SAGE: London)

Wirick D W, 2009 Public-Sector Project Management: Meeting the Challenges and Achieving Results (John Wiley \& Sons: Hoboken, NJ)

Wolf S, 2012, “Temporal Dimensions of Governance: A Critical Analysis of Projects”, in Sustainability and short-term policies: improving governance in spatial policy interventions Eds S Sjöblom, K Andersson, T Marsden, S Skerratt (Ashgate: Farnham) pp 181-200

Wolf S A, 2014, “U.S. Agrienvironmental Policy: Neoliberalization of Nature meets Old Public Management", in The Neoliberal Regime in the Agri-Food Sector: Crisis, Resilience and Restructuring Eds S A Wolf, A Bonanno (Earthscan/Routledge: Oxon) pp 191-206

Wynne-Jones S, 2013, “Connecting payments for ecosystem services and agri-environment regulation: An analysis of the Welsh Glastir Scheme" Journal of Rural Studies 31 7786 
Table 1. RCPP proposal evaluation criteria. Source: Based on USDA (2014, page 28-29).

\begin{tabular}{|c|c|}
\hline Criteria (weight) & Explanation \\
\hline Solutions (25\%) & $\begin{array}{l}\text { Successful partnerships will engage communities at the outset to } \\
\text { identify the resource management opportunities in a defined area } \\
\text { and then establish attainable and measurable goals for delivering on } \\
\text { those opportunities }\end{array}$ \\
\hline Contributions (30\%) & $\begin{array}{l}\text { Successful partnerships will bring an array of financial and } \\
\text { technical capabilities to projects }\end{array}$ \\
\hline Innovation (20\%) & $\begin{array}{l}\text { Successful partnerships will realize the full potential of RCPP by } \\
\text { drawing all of the program authorities into an integrated project so } \\
\text { that resource management solutions are achieved most cost } \\
\text { effectively }\end{array}$ \\
\hline Participation (25\%) & $\begin{array}{l}\text { Successful partnerships will bring a diverse array of stakeholders } \\
\text { into a project and capitalize on their unique capabilities to help } \\
\text { make a project successful }\end{array}$ \\
\hline
\end{tabular}


Table 2. Comparing the Regional Conservation Partnership Program (RCPP) and traditional agri-environmental programs of USDA Natural Resources Conservation Service (NRCS).

\begin{tabular}{|c|c|c|}
\hline & Traditional AEP programs & $\begin{array}{l}\text { Regional Conservation } \\
\text { Partnership Program (RCPP) }\end{array}$ \\
\hline $\begin{array}{l}\text { Organization } \\
\text { How is conservation } \\
\text { pursued? }\end{array}$ & $\begin{array}{l}\text { USDA provides funds and } \\
\text { technical assistance to } \\
\text { individual landowners to } \\
\text { implement NRCS-approved } \\
\text { conservation practices }\end{array}$ & $\begin{array}{l}\text { Short-term projects jointly } \\
\text { funded by USDA and private } \\
\text { partners develop capacity to } \\
\text { plan, implement, and assess } \\
\text { conservation }\end{array}$ \\
\hline $\begin{array}{l}\text { Actors } \\
\text { Who is engaged in } \\
\text { conservation? }\end{array}$ & $\begin{array}{l}\text { Private landowners (farmers } \\
\text { and ranchers) }\end{array}$ & $\begin{array}{l}\text { Private landowners, local } \\
\text { government, dedicated regional } \\
\text { authorities, universities, not- } \\
\text { for-profit organizations, private } \\
\text { firms }\end{array}$ \\
\hline $\begin{array}{l}\text { Problem scope } \\
\text { What is conserved? }\end{array}$ & $\begin{array}{l}\text { Conservation problems eligible } \\
\text { for funding defined in the Farm } \\
\text { Bill; Implementation of } \\
\text { standardized practices }\end{array}$ & $\begin{array}{l}\text { Conservation problems eligible } \\
\text { for funding defined in the Farm } \\
\text { Bill; Implementation of } \\
\text { standardized practices allowing } \\
\text { for a degree of flexibility }\end{array}$ \\
\hline
\end{tabular}

